\title{
Biodegradation of 2,6-Dichlorophenol Wastewater in Soil Column Reactor in the Presence of Pineapple Peels-Derived Activated Carbon, Palm Kernel Oil and Inorganic Fertilizer
}

\author{
Samuel E. Agarry ${ }^{*}$, Mujidat O. Aremu, Oluwafunmilayo A. Aworanti \\ Biochemical Engineering and Biotechnology Laboratory, Department of Chemical Engineering, Ladoke Akintola University of \\ Technology, Ogbomoso, Nigeria. \\ Email: *sam_agarry@yahoo.com, ${ }^{*}$ seagarry@lautech.edu.ng
}

Received January $30^{\text {th }}, 2013$; revised March $4^{\text {th }}, 2013$; accepted April $2^{\text {nd }}, 2013$

Copyright (C) 2013 Samuel E. Agarry et al. This is an open access article distributed under the Creative Commons Attribution License, which permits unrestricted use, distribution, and reproduction in any medium, provided the original work is properly cited.

\begin{abstract}
In this study, the potential effects of palm kernel oil (PKO), pineapple peels derived-activated carbon (PPAC) and NPK fertilizer (20:10:10) as amendment agents on the natural bioattenuation of 2,6-dichlorophenol (2,6-DCP) in tropical agricultural soil were investigated. The effect of PPAC dosage on 2,6-DCP biodegradation was also studied. Column reactors containing soil were spiked with 2,6-dichlorophenol (2,6-DCP) wastewater (300 mg/l) and amended with PKO, NPK fertilizer and PPAC alone or in combinations. The rates of 2,6-DCP biodegradation were studied for a remediation period of 42 days under laboratory conditions. The results showed that there was a positive relationship between the rate of 2,6-DCP biodegradation, bacterial growth rate and presence of NPK fertilizer and PPAC (alone or in combination) in soil column microcosms contaminated with 2,6-DCP. The 2,6-DCP biodegradation data fitted well to the first-order kinetic model. The model revealed that 2,6-DCP contaminated-soil microcosms amended with NPK fertilizer and PPAC (alone or in combination) had higher biodegradation rate constants $(k)$ as well as lower half-life times $\left(t_{1 / 2}\right)$ than soil column microcosms amended with PKO and unamended soil (natural attenuation) remediation system. Thus, the use of combined NPK fertilizer and activated carbon (NPK + PPAC) to enhance 2,6-DCP degradation in the soil could be one of the severally sought bioremediation strategies of remediating natural ecosystem (environment) contaminated with organic chemicals.
\end{abstract}

Keywords: Activated Carbon; Biodegradation; Fertilizer; Vegetable Oil; Kinetics; 2,6-Dichlorophenol

\section{Introduction}

The contamination of land and aquatic environment by hydrocarbons has become a serious problem in major parts of the world and Nigeria in particular. This represents a global concern for the potential consequences on ecosystem and human health [1]. Phenolic compounds including chlorophenols are frequently encountered components of industrial wastewaters and a major concern for environmental engineers. They comprise 10 out of 114 EPA-designated organic priority pollutants $[2,3]$. Chlorophenols constitute an important class of pollutants because of their wide use in the production of wood preservers, pesticides and biocides [4-6]. These compounds

"Corresponding author. are present in the wastewater generated from industrial activities such as petrochemical, pharmaceutical, wood preserving, plastic, rubber proofing, pesticide, iron steel, textile, and paper and cellulose bleaching industries [7,8]. Chlorophenols as environmental pollutants are highly toxic and carcinogenic with strong odour emission, not readily biodegradable and persistent in the environment and thus poses a serious ecological problem and public health risk causing problems with the human respiratory and nervous system [9-12]. For this reason an increasing attention has been directed toward the research of new strategies and environmental-friendly technologies to be applied for the remediation of ecosystems contaminated by hydrocarbons. Among these, biotechnological strategies based on the autochthonous microbial communities 
to biodegrade organic pollutants are of particular relevance.

Biological treatment has proved to be the most promising and economical method for the removal of phenolic compounds from the environment. It is believed to lead to complete mineralization of organic compound [13] and can handle a wide range of concentrations [14]. Microbial degradation of hydrocarbons is a predominant mechanism for natural attenuation at hydrocarbon-contaminated sites, but contaminant loss may also be attributed to abiotic processes such as sorption, volatilization, dilution, and dispersion [15]. Bioremediation techniques often include the addition of supplements or amendments to enhance bioavailability and biodegradation of petroleum hydrocarbons in natural soils/sediments by indigenous or inoculated microorganisms. The supplements can be divided into three general categories according to their impact on the microbial processes: surfactants that enhance the availability of the pollutants [16], specific cosubstrates that can play the role of alternate carbon source that promote the growth of a particular group of degraders [17-20] or act as mass transfer agent between the liquid phase of the soil and the solid matrix $[21,22]$ and organic and inorganic nutrients that increase the size and activity of the soil microbial community [23].

Vegetable oils are renewable and low cost co-substrates, used to enhance process efficiency without increasing significantly bioremediation costs. Vegetable oils such as peanut, sunflower and rapeseed oils have been found to be efficient in enhancing polycyclic aromatic hydrocarbons (PAHs) removal from contaminated soils [24-26]. The use of vegetable oils as co-substrates in the remediation of soil contaminated with monoaromatic hydrocarbons such as phenol and its substituted compounds have not been investigated. In many natural ecosystems a combination of biological and adsorption processes is a common phenomenon. Thus, combined methods of adsorption and biodegradation are nowadays gaining importance. The recent literature on methods of hydrocarbons removal from contaminated soil focuses on adsorption and microbial degradation process $[27,28]$. Recently, a growing interest in the sorption of organic contaminants to carbonaceous materials has drawn attention to treat contaminated soil/sediment, with the purpose of finding cheaper and functionally acceptable materials for the removal of contaminants. Previous studies have demonstrated that carbonaceous materials, such as peat [29], soybean stalk [30], coke [31], and activated carbon [32$34]$ can effectively reduce organic contaminants in soil/ sediment.

Activated carbon is most widely used as adsorbent in the removal of heavy metals and hazardous organic chemicals [35] because of its hydrophobicity, high specific surface $\left(8,001,200 \mathrm{~m}^{2} / \mathrm{g}\right)$, and microporous structure. In recent years, extensive researches are focused on the development of alternative and economic activated carbon from agricultural by-products [35-39] that are ubiquitous green waste in the environment and which may cause some serious environmental pollution when filling at a fixed site. However, the use of activated carbon derived from agricultural waste materials as adsorbents for the enhancement of hydrocarbon biodegradation rate in soil is very limited [28].

Therefore, the objective of this study were to use laboratory soil column reactor to investigate the catabolic potential of natural soil microbial communities to biodegrade target hydrocarbon pollutants (2,6-dichlorophenol) and also to evaluate the efficacy of adsorption and biostimulation during hydrocarbon degradation by natural microbial communities augmented with pineapple peels derived-activated carbon, palm kernel oil and NPK fertilizer additions.

\section{Materials and Methods}

\subsection{Collection of Samples}

The soil sample used for the study was collected from the top surface soil $(0-15 \mathrm{~cm})$ of Ladoke Akintola university of Technology (LAUTECH) agricultural farm land, Ogbomoso, Nigeria. The soil samples were air dried, homogenized, passed through a $2-\mathrm{mm}$ (pore size) sieve and stored in a polythene bag and kept in the laboratory prior to use. The chemicals 2,6-dichlorophenol (2,6-DCP) and n-hexane (analytical grade) being products of SigmaAldrich Chemical Co., were bought from a chemical store at Ibadan while NPK fertilizer used as nutrient supplement was purchased from an agrochemical store in Ogbomoso, Nigeria. Pineapple peels, a waste product of pineapple pulp used for the production of activated carbon were obtained from pineapple fruits bought from a local market at Ogbomoso, Nigeria.

\subsection{Characterization of Soil Sample}

The soil sample was characterized for total carbon (TOC), total nitrogen $(\mathrm{N})$, total phosphorus, moisture content, and $\mathrm{pH}$ according to standard methods. The $\mathrm{pH}$ was determined according to the modified method of McLean [40]; total organic carbon was determined by the modified wet combustion method [41] and total nitrogen was determined by the semi-micro-Kjeldhal method [42]. Available phosphorus was determined by Brays No.1 method [43] and moisture content was determined by the dry weight method. The total hydrocarbon degrading bacteria (THDB) populations was determined by the vapor phase transfer method [44]. The physicochemical 
characterized parameters are presented in Table $\mathbf{1}$.

\subsection{Preparation of Activated Carbon}

The pineapple peels as the precursor material for activated carbon preparation was well washed with water several times, sun-dried for two weeks and oven dried at $110^{\circ} \mathrm{C}$ for $3 \mathrm{~h}$. The dried sample was milled into small particle sizes. A known amount $(1 \mathrm{~kg})$ of the dried pineapple peels was pyrolyzed in a furnace (Vecstra, Model $184 \mathrm{~A}$, Italy) at a temperature of $300^{\circ} \mathrm{C}$ for $2 \mathrm{~h}$. The resulting biochar was collected and cooled at room temperature. The biochar material was then subjected to chemical activation (using phosphoric acid $\left(\mathrm{H}_{3} \mathrm{PO}_{4}\right)$ ) by weighing samples of the carbonized material into beakers and then soaked in excess phosphoric acid $\left(\mathrm{H}_{3} \mathrm{PO}_{4}\right)$ agitated for $3 \mathrm{~h}$. After the agitation, the mixtures were then charged inside an oven at a temperature of $200^{\circ} \mathrm{C}$ for 24 $\mathrm{h}$ to ensure proper adsorbate drying. The biochar samples were then removed from the oven and allowed to cool for $2 \mathrm{~h}$ after which they were washed with distilled water until leachable impurities due to free acid and adherent powder were removed. The samples were further soaked in $2 \%(\mathrm{w} / \mathrm{v})$ sodium bicarbonate $\left(\mathrm{NaHCO}_{3}\right)$ to remove any residual acid left. The resulting mixture were further washed with distilled water to bring the $\mathrm{pH}$ to 7.0 and finally drained and dried overnight in an oven at $110^{\circ} \mathrm{C}$ to get the final activated carbon product.

\subsection{Preparation of Simulated Dichlorophenol Wastewater}

A known amount $(2 \mathrm{~g})$ of 2,6-DCP was weighed and added to $1 \mathrm{~L}$ of de-ionized water in a glass bottle which was properly shaken for thorough dissolution to produce a stock simulated wastewater of $2 \mathrm{~g} / 12,6-\mathrm{DCP}$. This was kept in a refrigerator prior to use.

\subsection{Slurry-Phase Biodegradation Experimental Design}

A constructed column reactor using a $20 \mathrm{~mm}$ thick plastic glass (transparent material) with the dimensions 20.32 $\mathrm{cm}$ height by $10.16 \mathrm{~cm}$ width by $8.5 \mathrm{~cm}$ length and a volume capacity of $10 \mathrm{~L}$ was used to simulate reaction conditions occurring in the depth from which soil samples were collected. The aerobic biodegradation studies were conducted by spiking $1 \mathrm{~kg}$ of LAUTECH agricultural farm soil with $300 \mathrm{mg} / \mathrm{l}$ of the simulated dichlorophenol wastewater. Different amount of the pineapple peels-derived activated carbon (PPAC), PKO and NPK fertilizer was respectively added to the contaminated soil and thoroughly mixed together (Table 2). A control experiment which did not contain any of the amendments

Table 1. Physicochemical and microbiological properties of soil.

\begin{tabular}{cc}
\hline Parameter & Value \\
\hline Organic carbon (\%) & $1.05 \pm 0.01$ \\
Total nitrogen (\%) & $0.77 \pm 0.03$ \\
Phosphorus (\%) & $0.06 \pm 0.02$ \\
Potassium (\%) & $0.25 \pm 0.01$ \\
$\mathrm{pH}$ & $7 \pm 0.1$ \\
Moisture (\%) & $11.4 \pm 0.02$ \\
Total hydrocarbon degrading bacteria (THDB) CFU/g & $0.02 \pm 2.45 \times 10^{6}$ \\
\hline
\end{tabular}

Note: Each value is a mean of three replicates and \pm indicates standard deviation among them.

Table 2. Experimental design.

\begin{tabular}{cc}
\hline Soil Column Microcosm & Amount of Amendments \\
\hline A & Soil $+2,6-\mathrm{DCP}+1 \%$ PKO \\
B & Soil $+2,6-\mathrm{DCP}+5 \mathrm{~g} \mathrm{NPK}$ \\
C & Soil $+2,6-\mathrm{DCP}+10 \mathrm{~g}$ PPAC \\
D & Soil $+2,6-\mathrm{DCP}+5 \mathrm{~g} \mathrm{NPK}+1 \%$ PKO \\
E & Soil $+2,6-\mathrm{DCP}+10 \mathrm{~g}$ PPAC $+1 \%$ PKO \\
F & Soil $+2,6-\mathrm{DCP}+5 \mathrm{~g} \mathrm{NPK}+10 \mathrm{~g}$ PPAC \\
G & Soil $+2,6-\mathrm{DCP}+5 \mathrm{~g} \mathrm{NPK}+1 \%$ PKO $+10 \mathrm{~g}$ PPAC \\
H & Soil $+2,6-\mathrm{DCP}+15 \mathrm{~g}$ PPAC \\
I & Soil $+2,6-\mathrm{DCP}+20 \mathrm{~g}$ PPAC \\
J (Control) & Soil $+2,6-\mathrm{DCP}$ (No amendment $)$ \\
\hline
\end{tabular}


was set up alongside the experimental samples following the same procedure. The contaminated soil was then packed into the column reactor and incubated at ambient conditions for six weeks (42 days). The study was carried out during the rainy season between the month of October and November when the climate is cool and the temperature is usually not very high. The water (moisture) content of soil in each column reactor was adjusted every week by addition of sterile distilled water to a moisture holding capacity of $50 \%$. In order to avoid anaerobic conditions, contents of the column reactors were aerated by mixing every 3 days. Samples were taken every week and analyzed for residual dichlorophenol and total hydrocarbon-degrading bacteria (THDB), respectively. The experiments were carried out in triplicates.

\subsection{Determination of Residual Dichlorophenol}

For the determination of residual chlorophenol compound, soil-slurry samples were extracted with n-hexane, centrifuged for $20 \mathrm{~min}$ at $3000 \mathrm{rpm}$, and filtered through No. 2 Whatman filter paper. The clear supernatant organic phase was analyzed by means of a gas chromatograph, HP 6890 adapted to a mass spectrometer detector, model 5972 (GC-MS) and injector 7973. The GC-MS was equipped with a HP5MS and HP1 column of $30 \mathrm{~m}$ length, $0.25 \mathrm{~mm}$ internal diameter and $0.25 \mathrm{~lm}$ of film thickness. Helium was used as the carrier gas at a flow rate of $2.9 \mathrm{ml} \cdot \mathrm{min}^{-1}$. The conditions for analysis were: split 1:20; range of mass scan 50 - 500; with temperatures as follows: injector $260^{\circ} \mathrm{C}$, detector $280^{\circ} \mathrm{C}$; gradient program: $65^{\circ} \mathrm{C}$ to $96^{\circ} \mathrm{C}\left(4^{\circ} \mathrm{C} \cdot \mathrm{min}^{-1}\right), 96^{\circ} \mathrm{C}$ to $160^{\circ} \mathrm{C}$ $\left(8^{\circ} \mathrm{C} \cdot \mathrm{min}^{-1}\right)$ and up to $230^{\circ} \mathrm{C}\left(12^{\circ} \mathrm{C} \cdot \mathrm{min}^{-1}\right)$.

\subsection{Statistical Analysis}

One-way ANOVA (Tukey's test) was used to compare 2,6-DCP biodegradation in soil among different amend- ment agents and in unamended soil. Statistical analyses were performed using the Statistical Package Social Science (SPSS) software (Version 15.0; SPSS, Inc.).

\subsection{Biodegradation Kinetics and Estimation of Half-Life Time}

Kinetic analysis is a key factor for understanding biodegradation process, bioremediation speed measurement and development of efficient clean up for an organic chemical contaminated environment. Biodegradability of hydrocarbon can be explained by first order kinetics $[45,46]$ and this is given as in Equation (2):

$$
C_{t}=C_{o} \mathrm{e}^{-k t}
$$

where $C_{o}$ is the initial 2, 6-DCP content in soil $(\mathrm{mg} / \mathrm{kg})$, $C_{t}$ is the residual 2,6-DCP content in soil at time $t$, $(\mathrm{mg} / \mathrm{kg}), k$ is the biodegradation rate constant $\left(\right.$ day $\left.^{-1}\right)$ and $t$ is time (day).

The biodegradation half-life is the time taken for a substance to lose half of its amount. Biodegradation half life times $\left(t_{1 / 2}\right)$ are calculated using Equation (3) [46]:

$$
t_{1 / 2}=\frac{\ln 2}{k}
$$

where $k$ is the biodegradation rate constant $\left(\right.$ day $\left.^{-1}\right)$. The half life model is based on the assumption that the biodegradation rate of hydrocarbons positively correlated with the hydrocarbon pool size in soil [47].

\section{Results and Discussion}

\subsection{Effect of Amendment Agents on Natural Attenuation}

A general increase in the percentage degradation of 2,6-DCP was observed with time as shown in Figures 1 and 2 , respectively. These results indicate that 2,6-DCP

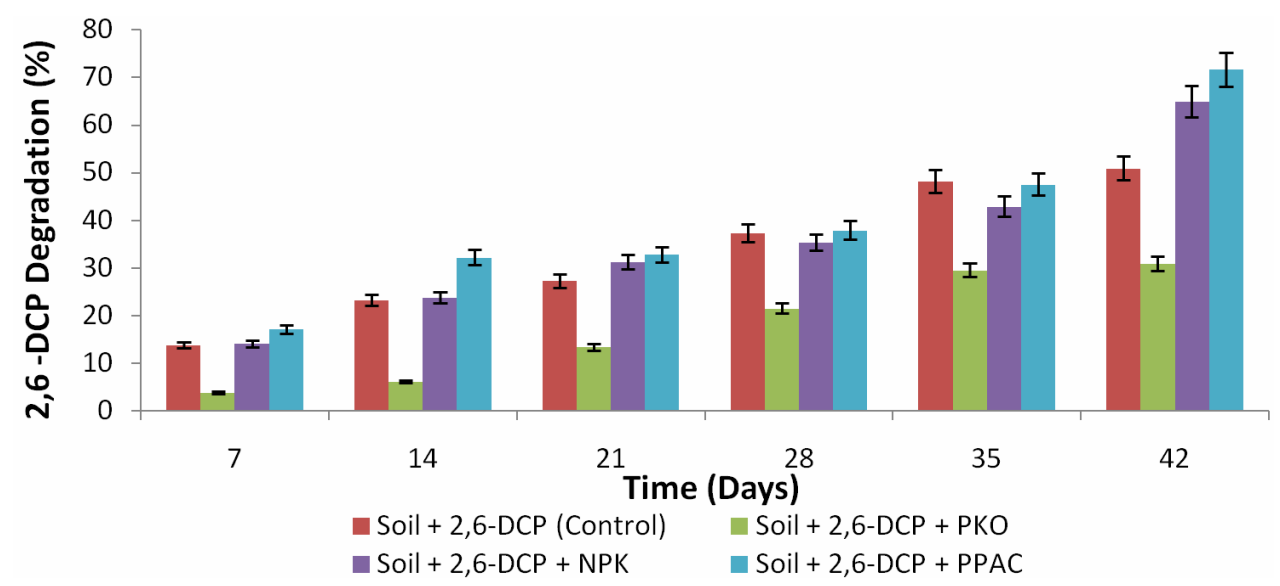

Figure 1. Percentage degradation of 2,6-DCP as a function of time in slurry soil amended with PKO, NPK, PPAC and unamended soil. 


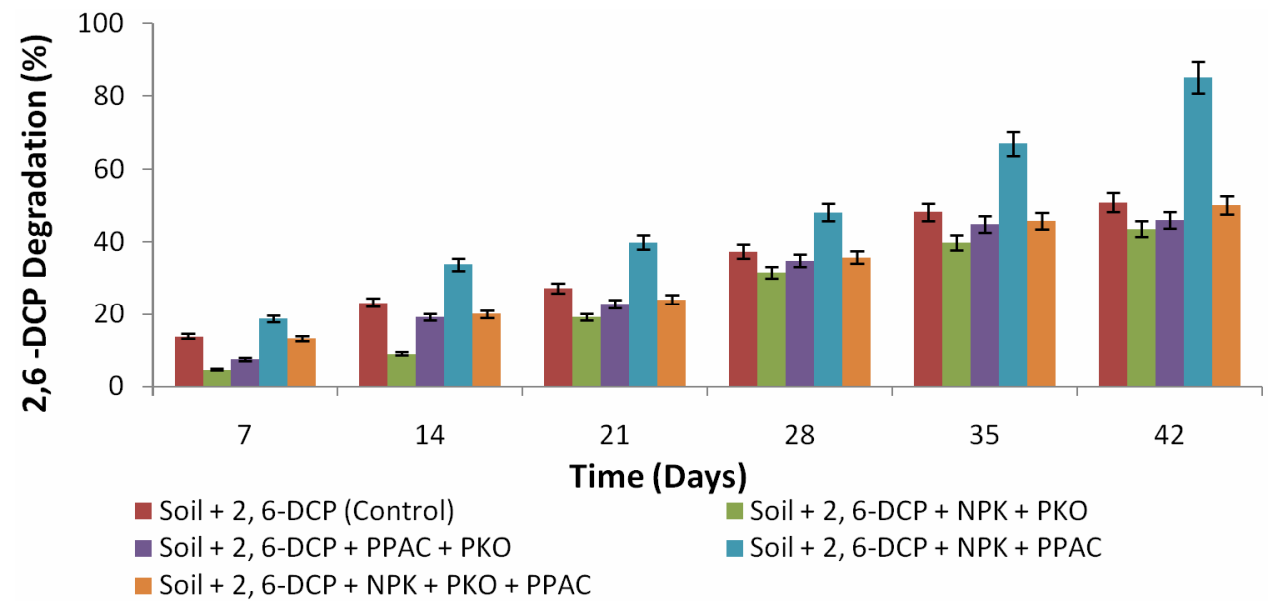

Figure 2. Percentage degradation of 2,6-DCP as a function of time in slurry soil amended with NPK + PKO, PPAC + PKO, NPK + PPAC, NPK + PKO + PPAC and unamended soil.

naturally degraded in the unamended slurry soil due to the presence of microorganisms present in the soil. The results in Figure 1 showed that the biodegradation rate of 2,6-DCP was greater in slurry soils amended respectively with PPAC and NPK fertilizer (with higher percentage degradation) than the unamended soil (natural attenuation). This observation could be due to the fact that PPAC acted as an adsorbent in the soil as well as cometabolic carbon substrate while the NPK fertilizer provided inorganic nutrients to the autochthonous microorganisms in the soil. Enhanced bioremediation of soil highly contaminated with herbicide propanil (3',4'-dichloropropionanilide) in the Krasnodar region of Russia, 3,4-dichloroaniline, polychlorinated biphenyls (PCB) and 2,4,6-trinitrotoluene (TNT) in the presence of activated carbon have been reported [48-52]. Accelerated biodegradation of anthracene in the presence of groundnut shellderived activated carbon has been reported by Owabor and Aluyor [28] while Lou et al. [53] have also observed accelerated biodegradation of pentachlorophenol in soil in the presence of bamboo biochar.

However, the percentage degradation of 2,6-DCP in PPAC-amended soil is relatively greater than the NPK fertilizer-amended soil. While the percentage degradation in soil amended with PKO was lower than that of unamended soil (natural attenuation) and this indicates that rate of biodegradation was faster in the latter than the former. Vegetable oils have been proposed as natural, cost-effective and non-toxic solvents. Nevertheless, the lower percentage degradation observed in PKO-amended soil suggests that the PKO was inhibitory to the soil microorganisms' metabolic functions. This inhibitory effect may be due to the high amount of oil used in this work which restrained the biological processes and inhibited the degradation of 2,6-DCP [54]. Pizzul et al. [54] have reported the inhibitory effect of rapeseed oil on indige- nous soil microorganism which resulted in lower percentage degradation of phenanthrene and pyrene when compared to the control soil without rapeseed oil. They attributed this observation as due to high amount of rapeseed oil $(1 \% \mathrm{w} / \mathrm{w})$ that was used. However, these same workers have also reported the stimulatory effect of rapeseed oil which led to higher degradation values for anthracene and benzo(a)pyrene as compared to the control soil without rapeseed oil. Pannu et al. [55] reported the effects of small amounts of vegetable oil on the biodegradation of polycyclic aromatic hydrocarbon (PAH). The presence of $0.2 \%(\mathrm{v} / \mathrm{v})$ of peanut oil had a stimulatory effect on the degradation of polycyclic aromatic hydrocarbon (PAH) in a soil slurry bioreactor system. The beneficial effect was attributed to the solubilization of the PAH in the oil and subsequent transfer to the bacterial cells associated with the oil drops and to the promotion of biosurfactant production.

The influence of two or three level combination of the amendment agents on 2,6-DCP biodegradation in soil is shown in Figure 2. It could be seen that among the two or three level combination of amendment agents, the slurry soil amended with the combination of NPK fertilizer and pineapple peel-derived activated carbon (NPK + PPAC) displayed the highest percentage degradation of 2,6-DCP as compared to percentage degradation in soil amended with NPK + PKO, PPAC + PKO, and the unamended soil (natural attenuation). The percentage degradations of 2,6-DCP in soils amended with NPK + PKO and PPAC + PKO are respectively lower than that in unamended soil. On the other hand, the percentage degradation of 2,6-DCP in soil amended with NPK + PKO and PPAC + PKO was respectively higher than the percentage degradation in soil amended with PKO only. This improvement may be due to the supply of nutrients by the NPK fertilizer as well as due to the adsorptive 
capacity of PPAC and ability to act as co-metabolic carbon substrate to the autochthonous microorganisms in the soil. However, there is no statistical significant difference $(p<0.05)$ in the percentage degradation of 2,6-DCP in soil amended with NPK + PKO and PPAC + PKO.

\subsection{Effect of Amendment on the Microbial Growth}

Figure 3 shows the growth profile of the hydrocarbon degrading bacterial population in the slurry soil. An initial hydrocarbon-degrading bacterial population of about $1.1 \times 10^{6}, 1.8 \times 10^{6}, 2.0 \times 10^{6}$, and $1.6 \times 10^{6} \mathrm{CFU} / \mathrm{g}$ was observed respectively before the start of remediation for slurry soil amended with PKO, NPK fertilizer, PPAC, and unamended soil as shown in Figure 3. As seen from Figure 3, at the end of incubation (day 42), the THDB count had increased to a maximum bacterial population of $2.8 \times 10^{6}, 7.9 \times 10^{6}, 12.5 \times 10^{6}$, and $5.4 \times 10^{6} \mathrm{CFU} / \mathrm{g}$ which corresponded to $60.7 \%, 77.2 \%, 84 \%$ and $70.4 \%$ for slurry soil amended with PKO, NPK, PPAC, and unamended soil, respectively. However, the growth rate of THDB in soil amended with PKO was lower (resulting in lower percentage degradation of 2,6-DCP) as compared to the growth rate of THDB in soil amended with NPK fertilizer, PPAC and unamended soil, respectively. This observation may be due to the inhibitory effect of PKO on the autochthonous microorganisms in the soil.

Similarly, as shown in Figure 4, the THDB count in-

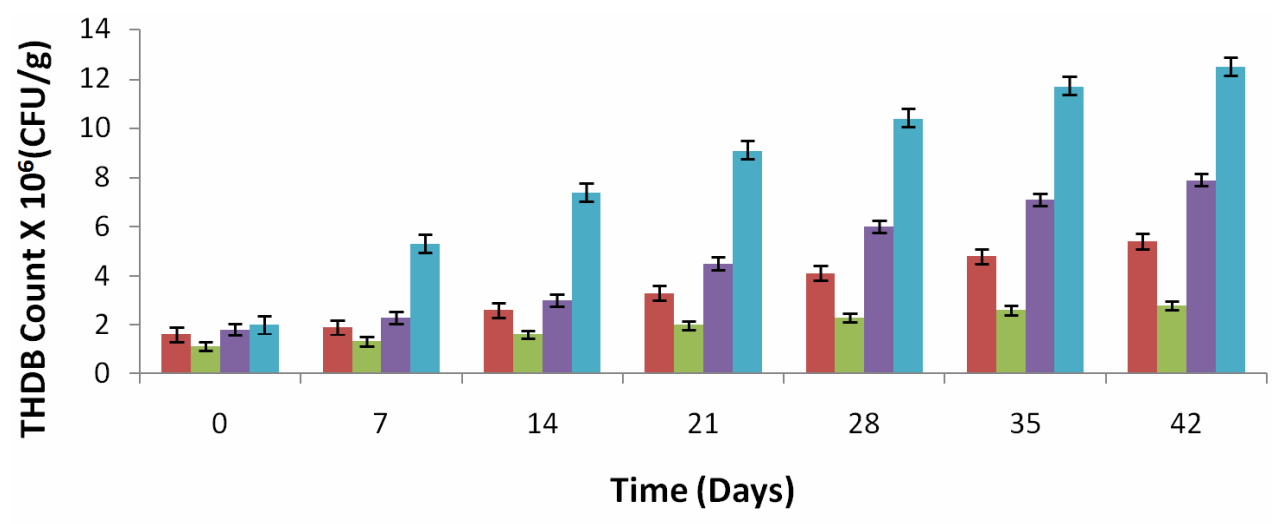

$$
\begin{aligned}
& \square \text { Soil + 2,6-DCP (Control) } \square \text { Soil + 2,6-DCP + PKO } \\
& \square \text { Soil + 2,6-DCP + NPK } \square \text { Soil + 2,6-DCP + PPAC }
\end{aligned}
$$

Figure 3. Bacterial growth on 2,6-DCP as a function of time in slurry soil amended with PKO, NPK, PPAC and unamended soil.

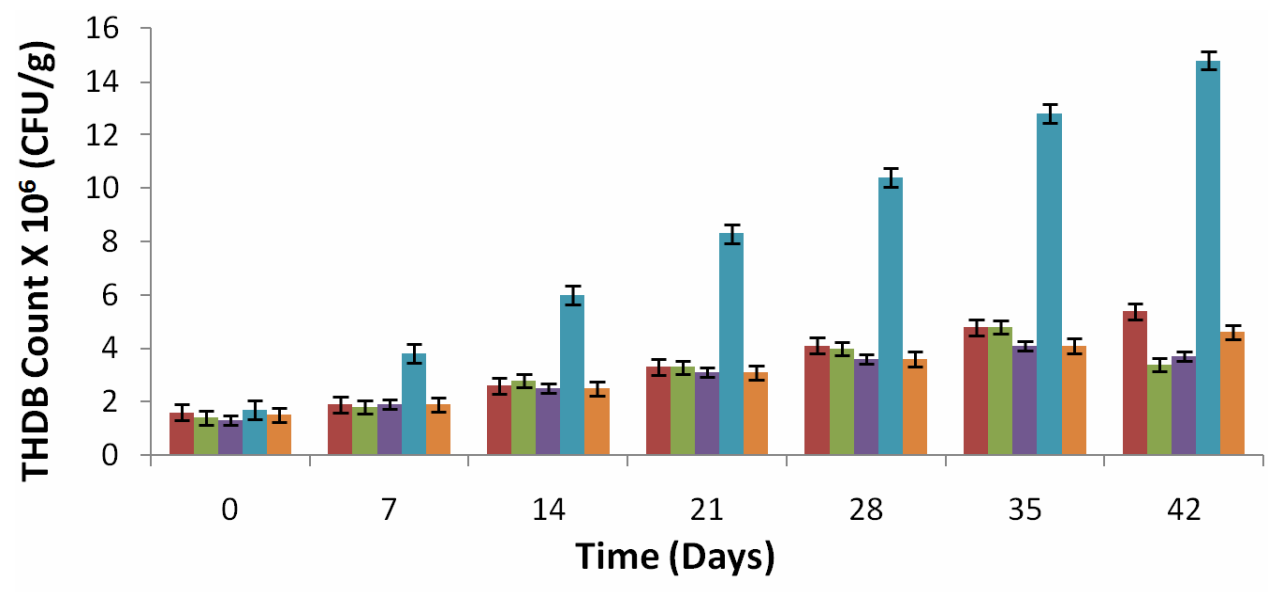

$$
\begin{aligned}
& \text { - Soil + 2,6-DCP (Control) } \\
& \text { - Soil + 2,6-DCP + PPAC + PKO }
\end{aligned}
$$

$$
\begin{aligned}
& \text { Soil + 2,6-DCP + NPK + PKO } \\
& \text { Soil + 2,6-DCP + NPK + PPAC }
\end{aligned}
$$

Figure 4. Bacterial growth on 2,6-DCP as a function of time in soil amended with NPK + PKO, PPAC + PKO, NPK + PPAC, NPK + PKO + PPAC and unamended soil. 
creased from $1.4 \times 10^{6}, 1.3 \times 10^{6}, 1.7 \times 10^{6}$, and $1.5 \times$ $10^{6} \mathrm{CFU} / \mathrm{g}$ (day 0) to $3.4 \times 10^{6}, 3.7 \times 10^{6}, 14.8 \times 10^{6}$, and $4.6 \times 10^{6} \mathrm{CFU} / \mathrm{g}$ (day 42 ) corresponding to a growth increase of $58.8 \%, 64.9 \%, 88.5 \%$ and $70.2 \%$ for slurry soil amended with NPK + PKO, PPAC + PKO, NPK + PPAC, and NPK + PKO + PPAC, respectively. This observation indicated that the growth rate of the hydrocarbon degrading bacteria was higher in slurry soil amended with NPK + PPAC (resulting in higher percentage degradation of 2,6-DCP) than that amended with NPK + PKO, PPAC $+\mathrm{PKO}, \mathrm{NPK}+\mathrm{PKO}+\mathrm{PPAC}$, and the unamended soil (natural attenuation), respectively. Furthermore, the rate of bacteria growth in soil amended with NPK + PKO and PPAC + PKO are respectively lower than that in the unamended soil but higher than the growth rate in soil singly amended with PKO. The higher growth rate observed in soil amended with NPK + PKO and PPAC + PKO than that in soil amended with only PKO is due to the presence of inorganic nutrient provided by NPK fertilizer and the adsorption mechanism provided by PPAC, respectively. Nevertheless, there is no statistical significant difference $(\mathrm{p}<0.05)$ in the growth rate of bacteria (THDB) in slurry soil amended with NPK + PKO and PPAC + PKO as well as in slurry soil amended with $\mathrm{NPK}+\mathrm{PKO}+\mathrm{PPAC}$ and the unamended soil.

\subsection{Biodegradation Kinetics and Half-Life}

Fitting the biodegradation data obtained for each soil treatment to first-order kinetic model using the non-linear regression routine of MATLAB 7.0 software package made possible further evaluation and comparison of the applicability of the various amendment strategies. The parameter " $k$ " of the model, being the specific degradation rate constants for biodegradation of 2,6-DCP in the soil, was determined for soil treatment amended singly with PKO, NPK fertilizer, and PPAC as well as for those amended with two or three level combinations (NPK + PKO, PPAC + PKO, NPK + PPAC, and NPK + PKO + PPAC), respectively. The results are presented in Table 3. The results indicate that the " $k$ " value $\left(0.0211\right.$ day $\left.^{-1}\right)$ for the biodegradation of 2,6-DCP in soil amended with
PPAC was comparatively higher than the value for soil amended with NPK (0.0189 $\left.\mathrm{day}^{-1}\right)$ and PKO (0.0095 day $^{-1}$ ), respectively. The soil treatment with PKO only had the smallest " $k$ " value $\left(0.0095\right.$ day $\left.^{-1}\right)$ while the $k$ value for the biodegradation of 2,6-DCP in unamended soil (natural attenuation) is $0.0170 \mathrm{day}^{-1}$. More also, the $k$ value $\left(0.0309 \mathrm{day}^{-1}\right)$ for the biodegradation of 2,6-DCP in soil amended with NPK + PPAC was relatively higher than that amended with NPK + PKO $\left(0.0142\right.$ day $\left.^{-1}\right)$, PPAC + PKO $\left(0.0156\right.$ day $\left.^{-1}\right)$ and NPK + PKO + PPAC $\left(0.0161\right.$ day $\left.^{-1}\right)$, respectively. However, the $k$ values for 2,6-DCP biodegradation in soil amended with NPK + PKO and PPAC + PKO are comparatively lower than that in unamended soil (natural attenuation).

The biodegradation half-life times was calculated using Equation (2) and the values are presented in Table 3. Lower the half-life value and faster the rate of degradation. The soil treatment with the lower half-life has the best performance. As seen from Table 3, half-life of 40.72 days was observed for the biodegradation of 2,6DCP in unamended contaminated soil (control soil or natural attenuation). This was reduced to lesser number of days in 2,6-DCP-contaminated soil amended with NPK fertilizer and PPAC (either singly or in combination), respectively. Nevertheless, 2,6-DCP contaminated soil amended with PKO had the highest half-life (73.9 days). Therefore, values of the kinetic parameter and half-life showed that the degree of effectiveness of these amendment strategies in the cleanup of soil contaminated with 2,6-DCP is in the following order: $\mathrm{PKO}<\mathrm{NPK}+\mathrm{PKO}<$ $\mathrm{PPAC}+\mathrm{PKO}<\mathrm{NPK}+\mathrm{PKO}+\mathrm{PPAC}<$ natural attenuation $<$ NPK $<$ PPAC $<$ NPK + PPAC.

\subsection{Effect of Activated Carbon Dose}

Figure 5 shows the effect of PPAC dosage on the percentage degradation of 2,6-DCP in soil. It was observed that the percentage degradation of 2,6-DCP in soil increased with the increase in the PPAC dosage. A similar observation has been reported for the use of bamboo biochar on pentachlorophenol leachability and bioavailability in agricultural soil [53].

Table 3. Specific degradation rate constants $(k)$, correlation coefficient $\left(R^{2}\right)$ and half-life $\left(t_{1 / 2}\right)$ for 2 , 6-DCP biodegradation in soil.

\begin{tabular}{cccc}
\hline Soil Treatment & $k\left(\right.$ day $\left.^{-1}\right)$ & $R^{2}$ & $t_{1 / 2}($ days $)$ \\
\hline Soil + 2,6-DCP + PKO & 0.0095 & 0.9581 & 73.14 \\
Soil + 2,6-DCP + NPK & 0.0189 & 0.9343 & 36.55 \\
Soil + 2,6-DCP + PPAC & 0.0211 & 0.8981 & 32.78 \\
Soil + 2,6-DCP + NPK + PKO & 0.0142 & 0.9589 & 48.77 \\
Soil + 2,6-DCP + PPAC + PKO & 0.0156 & 0.9808 & 44.48 \\
Soil + 2,6-DCP + NPK + PPAC & 0.0309 & 0.9380 & 22.46 \\
Soil + 2,6-DCP + NPK + PKO + PPAC & 0.0161 & 0.9812 & 43.02 \\
Soil + 2,6-DCP (Natural attenuation) & 0.0170 & 0.9867 & 40.72 \\
\hline
\end{tabular}




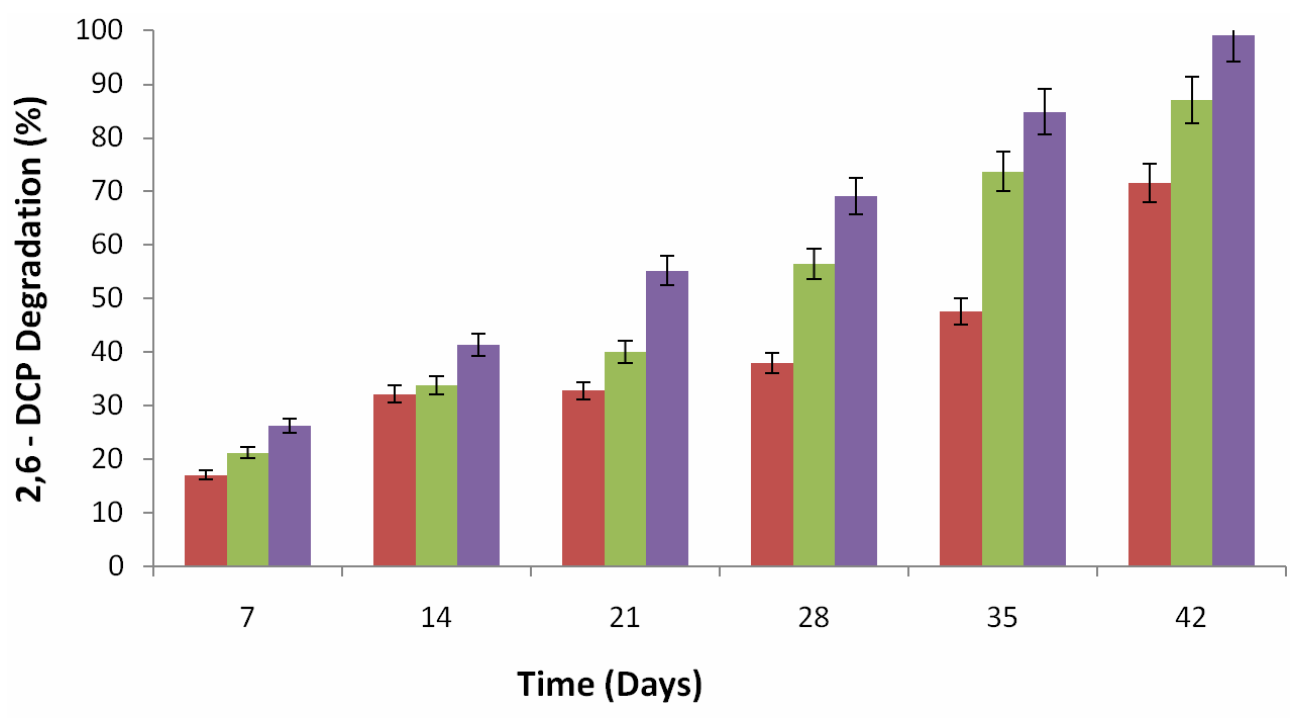

Soil + 2,6-DCP $+10 \mathrm{~g}$ PPAC Soil $+2,6-\mathrm{DCP}+15 \mathrm{~g}$ PPAC $\square$ Soil $+2,6-\mathrm{DCP}+20 \mathrm{~g}$ PPAC

Figure 5. Effect of activated carbon dosage on percentage degradation of 2,6-DCP.

\section{Conclusion}

From this present study, it can be concluded that the addition of activated carbon, prepared from pineapple peels waste (PPAC) as well as the addition of NPK fertilizer alone or in combination, significantly $(P<0.05)$ enhanced the biodegradation of 2,6-DCP and the rate of growth of autochthonous microorganisms in soil columns and thus decrease the time for complete bioremediation. While the addition of co-metabolic carbon substrate in the form of vegetable oil (PKO) slows down the biodegradation rate of 2,6-DCP and the growth rate of autochthonous microorganisms in soil. The soil treatment under NPK + PPAC amendment (combined biostimulation and adsorptive bioremediation) exhibited the highest degree of degradation and the soil treatment under PKO amendment the least degradation. Furthermore, because of the high efficiency, beneficial ecological effects and abundant sources of pineapple peels, it is a potentially attractive material for activated carbon development which can be used for in situ remediation to control organic pollution in soil and to protect surface and ground water from organic pollutants. Thus, the use of combined NPK fertilizer and activated carbon (biostimulation and adsorption-biodegradation) to enhance 2,6-DCP degradation in the soil could be one of the severally sought bioremediation strategies of remediating natural ecosystem (environment) contaminated with organic chemicals.

\section{REFERENCES}

[1] N. E. Onwurah, V. N. Ogugua, N. B. Onyike, A. E. Ochonogor and O. F. Otitoju, "Crude Oil Spills in the Envi- ronment, Effects and Some Innovative Clean-Up Biotechnologies," International Journal of Environmental Research, Vol. 1, No. 4, 2007, pp. 307-320.

[2] W. W. Eckenfelder Jr., "Industrial Water Pollution Controll," 2nd Edition, McGraw-Hill Publishers, New York, 1989.

[3] B.-H. Bae, R. L. Autenrieth and J. S. Bonner, "Kinetics of Multiple Phenolic Compounds Degradation with a Mixed Culture in a Continuous Flow Reactor," Water Environmental Research, Vol. 67, No. 2, 1995, pp. 215-223. doi:10.2175/106143095X131376

[4] H. Bae, T. Yamagishi and Y. Suwa, "Evidence for Degradation of 2-Chlorophenol by Enrichment Cultures under Denitrifying Conditions," Microbiology, Vol. 148, 2002, pp. 221-227.

[5] A. P. Annachhatre and S. H. Gheewala, "Biodegradation of Chlorinated Phenolic Compounds," Biotechnology Advances, Vol. 14, No. 1, 1996, pp. 35-56. doi:10.1016/0734-9750(96)00002-X

[6] K. A. Short, J. D. Doyle, R. J. King, R. J. Seidler, G. Stotzky and R. H. Olsen, "Effects of 2, 4-Dichlorophenol, a Metabolite of a Genetically Engineered Bacterium, and 2, 4-Dichlorophenoxyacetate on Some MicroorganismsMediated Ecological Processes in Soil," Applied Environmental Microbiology, Vol. 57, No. 2, 1991, pp. 412418.

[7] N. Fattahi, Y. Assadi and M. R. Hosaseini, "Determination of Chlorophenols in Water Sample Using Simultaneous Dispersive Liquid-Liquid Microextraction and Derivatization Followed by Gas Chromatography-ElectronCapture Detection," Journal of Chromatography A, Vol. 1157, No. 1-2, 2007, pp. 23-29.

[8] B. K. Hamad, A.-Md. Noor and A.A. Rahim, "Removal of 4-Chloro-2-Methoxyphenol from Aqueous Solution by Adsorption to Oil Palm Shell Activated Carbon Activated 
with $\mathrm{K}_{2} \mathrm{CO}_{3}$," Journal of Physical Sciences, Vol. 22, No. 1, 2011, pp 39-55.

[9] Agency for Toxic Substance and Disease Registry, "Toxicological Profile for Chlorophenols," US Department of Health and Human Services, Public Health Service, Atlanta, 1989.

[10] D. C. Yee and T. K. Wood, "2,4-Dichlorophenol Degradation Using Streptomyces Viridosporus T7A Lignin Peroxidase," Biotechnology Progress, Vol. 13, No. 1, 1997, pp. 53-59. doi:10.1021/bp960091x

[11] P. M. Armenante, D. Kafkewitz, G. A. Lewandowski and C. J. Jou, "Anaerobic-Aerobic Treatment of Halogenated Phenolic Compounds," Water Research, Vol. 33, No. 3, 1999, pp. 681-692. doi:10.1016/S0043-1354(98)00255-3

[12] I. A. W. Tan, A. L. Ahmad and B. H. Hameed, "Adsorption Isotherm, Kinetics, Thermodynamics and Desorption Studies of 2,4,6-Trichlorophenol on Oil Palm Empty Fruit Bunch-Based Activated Carbon," Journal of Hazardous Material, Vol. 164, No. 2-3, 2009, pp. 473-482. doi:10.1016/i.jhazmat.2008.08.025

[13] A. Nuhoglu and B. Yalcin, "Modeling of Phenol Removal in a Batch Reactor," Process Biochemistry, Vol. 40, No. 3-4, 2005, pp. 1233-1239. doi:10.1016/i.procbio.2004.04.003

[14] M. H. El-Naas, S. A. Al-Muhtaseb and S. Makhlouf, "Biodegradation of Phenol by Pseudomonas Putida Immobilized in Polyvinyl Alcohol (PVA) Gel," Journal of Hazardous Material, Vol. 164, No. 2-3, 2009, pp. 720-725. doi:10.1016/j.jhazmat.2008.08.059

[15] P. B. Bedient H. S. Rifai and C. J. Newell, "Groundwater Contamination, Transport and Remediation," Prentice Hall, Englewood Cliffs, 1994

[16] P. P. E. Carriere and F. A. Mesania, "Enhanced Biodegradation of Creosote-Contaminated Soil," Waste Management, Vol. 15, No. 8, 1995, pp. 579-583.

[17] J. W. C. Wong, K. M. Lai, K. K. Ma and M. Fang, "Isolation and Optimization of PAH-Degradative Bacteria from Contaminated Soil for PAHs Bioremediation," Water Air Soil Pollution, Vol. 139, No. 1-4, 2002, pp. 1-13. doi:10.1023/A:1015883924901

[18] P. H. Lee, K. J. Doick and K. T. Semple, "The Development of Phenanthrene Catabolism in Soil Amended with Transformer Oil," FEMS Microbiology Letters, Vol. 228, No. 2, 2003, pp. 217-223 doi:10.1016/S0378-1097(03)00751-1

[19] D. Sarkar, M. Ferguson, R. Datta and S. Birnbaum, "Bioremediation of Petroleum Hydrocarbons in Contaminated Soils: Comparison of Biosolids Addition, Carbon Supplementation, and Monitored Natural Attenuation," Environmental Pollution, Vol. 136, No. 1, pp. 187-195. doi:10.1016/j.envpol.2004.09.025

[20] S. Llado, N. Jime'nez, M. Vin as and A. M. Solanas, "Microbial Populations Related to PAH Biodegradation in an Aged Biostimulated Creosote-Contaminated Soil," Biodegradation, Vol. 20, No. 5, 2009, pp. 593-601. doi:10.1007/s10532-009-9247-1

[21] X. D. Huang, Y. El-Alawi, D. M. Penrose, B. R. Glick and B. M. Grenberg, "Responses of Three Grass Species to Cresote during Phytoremediation," Environmental Pollution, Vol. 130, No. 3, 2004, pp. 453-464. doi:10.1016/i.envpol.2003.12.018

[22] M. Mellendorf, G. Soja, H. Martin, M. H. Gerzabek and A. Watzinger, "Soil Microbial Community Dynamics and Phenanthrene Degradation as Affected by Rape Oil Application," Applied Soil Ecology, Vol. 46, No. 3, 2010, pp. 329-334. doi:10.1016/j.apsoil.2010.10.008

[23] L. M. Carmichael and F. K. Pfaender, "The Effect of Inorganic and Organic Supplements on the Microbial Degradation of Phenanthrene and Pyrene in Soils," Biodegradation, Vol. 8, No. 1, 1997, pp. 1-13. doi:10.1023/A:1008258720649

[24] J. H. Berg Schuur and B. Mattiasson, "Separation of Coal-Tar Constituents from Soil Particles in a Two-Liquid Phase Slurry System," Environmental Technology, Vol. 24, No. 6, 2003, pp. 755-765. doi:10.1080/09593330309385612

[25] J. K. Pannu, A. Singh and O. P. Ward, "Vegetable Oil as a Contaminated Soil Remediation Amendment: Application of Peanut Oil for Extraction of Polycyclic Aromatic Hydrocarbons from Soil," Process Biochemistry, Vol. 39, No. 10, 2004, pp. 1211-1216. doi:10.1016/S0032-9592(03)00254-1

[26] Z. Gong, K. Alef, B.-M. Wilke and P. Li, "Dissolution and Removal of PAHs from a Contaminated Soil Using Sunflower Oil," Chemosphere, Vol. 58, No. 3, 2005, pp. 291-298. doi:10.1016/j.chemosphere.2004.07.035

[27] S. B. Kim, D. J. Kim, S. Lee and W. A. Jury, "Effect of Sorption on Benzene Biodegradation in Sandy Soil," Environmental Toxicology and Chemistry, Vol. 22, No. 10, 2003, pp. 2306-2311. doi:10.1897/02-511

[28] C. N. Owabor and E. O. Aluyor, "Application of Adsorbent as a Novel Technique during Biodegradation of a Polycyclic Aromatic Hydrocarbon (Anthracene)," African Journal of Biotechnology, Vol. 7, No. 18, 2008, pp. 33213325.

[29] B. Wen, R. J. Li, S. Z. Zhang, X. Q. Shan, J. Fang, K. Xiao and S. U. Khan, "Immobilization of Pentachlorophenol in Soil Using Carbonaceous Material Amendments," Environmental Pollution, Vol. 157, No. 3, 2009 , pp. 968-974. doi:10.1016/j.envpol.2008.10.015

[30] J. Tang and W. J. Weber, "Development of Engineered Natural Organic Sorbents for Environmental Applications. 2. Sorption Characteristics and Capacities with Respect to Phenanthrene," Environmental Science and Technology, Vol. 40, No. 5, 2006, pp. 1657-1663. doi:10.1021/es051665+

[31] J. R. Zimmerman, U. Ghosh, R. N. Millward, T. S. Bridges and R. G. Luthy, "Addition of Carbon Sorbents to Reduce PCB and PAH Bioavailability in Marine Sediments: Physicochemical Tests," Environmental Science and Technology, Vol. 38, No. 20, 2004, pp. 5458-5464. doi:10.1021/es034992v

[32] S. P. Pradhan and V. J. Srivastava, "A Pilot-Scale Demonstration of an Innovative Soil Remediation Process: Air Emissions Quality," Journal of Air Waste Management 
Association, Vol. 47, No. 6, 1997, pp. 710-715. doi:10.1080/10473289.1997.10463928

[33] A. P. Khodadoust, G. A. Sorial, G. J. Wilson, M. T. Suidan, R. A. Griffiths and R. C. Brenner, "Integrated System for Remediation of Contaminated Soils," Journal of Environmental Engineering-ASCE, Vol. 125, No. 11, 1999, pp. 1033-1041. doi:10.1061/(ASCE)0733-9372(1999)125:11(1033)

[34] R. N. Millward, T. S. Bridges, U. Ghosh, J. R. Zimmerman and R. G. Luthy, "Addition of Activated Carbon to Sediments to Reduce PCB Bioaccumulation by a Polychaete (Neanthes arenaceodentata) and an Amphipod (Leptocheirus plumulosus)," Environmental Science and Technology, Vol. 39, No. 8, 2005, pp. 2880-2887. doi:10.1021/es048768x

[35] B. H. Hameed, "Spent Tea Leaves: A New Non-Conventional and Low-Cost Adsorbent for Removal of Basic Dye from Aqueous Solution," Journal of Hazardous Material, Vol. 161, No. 2-3, 2009, pp. 253-259. doi:10.1016/j.jhazmat.2008.04.019

[36] Y. Li, B. Chen and L. Zhu, "Enhanced Sorption of Polycyclic Aromatic Hydrocarbons from Aqueous Solution by Modified Pine Bark," Bioresource Technology, Vol. 101, No. 19, 2010, pp. 7307-7313. doi:10.1016/j.biortech.2010.04.088

[37] B. Chen, M. Yuana and H. Liu, "Removal of Polycyclic Aromatic Hydrocarbons from Aqueous Solution Using Plant Residue Materials as a Biosorbent," Journal of Hazardous Material, Vol. 188, No. 1-3, 2011, pp. 436-442. doi:10.1016/j.jhazmat.2011.01.114

[38] A. O. Alade, O. S. Amuda, T. J. Afolabi and A. A. Okoya, "Adsorption of Naphthalene onto Activated Carbons Derived from Milk Bush Kernel Shell and Flamboyant Pod," Journal of Environmental Chemistry and Ecotoxicology, Vol. 4, No. 7, 2012, pp. 124-132.

[39] S. E. Agarry and C. N. Owabor, "Evaluation of the Adsorption Potential of Rubber (Hevea brasiliensis) Seed Pericarp-Activated Carbon in Abattoir Wastewater Treatment and in the Removal of Iron (iii) Ions from Aqueous Solution," Nigerian Journal of Technology, Vol. 31, No. 3, pp. 1-14.

[40] E. O. McLean, "Soil pH and Lime Requirement," In: C. A. Black, Ed., Methods in Soil Analysis: Chemical and Microbiological Properties, WI American Society of Agronomy, Madison, 1982.

[41] D. W. Nelson and L. E. Sommers, "Determination of Organic Carbon," In: A. L. Page, R. H. Miller and D. R. Keeney, Eds., Method of Soil Analysis, American Society of Agronomy, Madison, 1982, p. 539.

[42] J. M. Bremner and C. S. Mulvaney, "Total Nitrogen Determination," In: A. L. Page, R. H. Miller and D. R. Keeney, Eds., Method of Soil Analysis, Vol. 2, American Society of Agronomy, Madison, 1982, p. 595.

[43] S. R. Olsen and L. E. Sommers, "Determination of Available Phosphorus," In: A. L. Page, R. H. Miller and D. R. Keeney Eds., Method of Soil Analysis, American Society of Agronomy, Madison, 1982, p. 403.

[44] S. C. Amanchukwu, A. Obafemi and G. C. Okpokwasili,
"Hydrocarbon Degradation and Utilization by a Palm Wine Yeast Isolates," FEMS Microbiology Letters, Vol. 57, No. 2, 1989, pp. 151-154. doi:10.1111/j.1574-6968.1989.tb03290.x

[45] S. E. Agarry, C. N. Owabor and R. O. Yusuf, "Bioremediation of Soil Artificially Contaminated with Petroleum Hydrocarbon Mixtures: Evaluation of the use of Animal Manure and Chemical Fertilizer," Bioremediation Journal, Vol. 14, No. 4, 2010, pp. 189-195. doi:10.1080/10889868.2010.514965

[46] M. A. Zahed, H. Abdul Aziz, M. H. Isa, L. Mohajeri, S. Mohajeri and S. R. M. Kutty, "Kinetic Modeling and Half Life Study on Bioremediation of Crude Oil Dispersed by Corexit 9500," Journal of Hazardous Material, Vol. 185, No. 2-3, 2011, pp. 1027-1031. doi:10.1016/j.jhazmat.2010.10.009

[47] P. Y. Yeung, R. L. Johnson and J. G. Xu, "Biodegradation of Petroleum Hydrocarbons in Soil as Affected by Heating and Forced Aeration," Journal of Environmental Quality, Vol. 26, 1997, pp. 1511-1576. doi:10.2134/jeq1997.00472425002600060009x

[48] G. K. Vasilyeva, L. P. Bakhaeva and E. G. Surovtseva, "The Use of in Situ Soil Adsorptive Bioremediation Following an Accidental Spill of Propanil in the Krasnodar Region of Russia," Land Contamination and Reclamation, Vol. 4, No. 4, 1996, pp. 263-268.

[49] G. K. Vasilyeva, V. D. Kreslavski, P. J. Shea and B.-T. Oh, "Potential of Activated Carbon to Decrease 2,4,6-Trinitritoluene Toxicity and Accelerate Soil Decontamination," Environmental Toxicology and Chemistry, Vol. 20, No. 5, 2001, pp. 965-971. doi:10.1002/etc.5620200505

[50] G. K. Vasilyeva, V. D. Kreslavski, P. J. Shea and J.-M. Bollag, "Accelerated Transformation and Binding of 2,4,6Trinitrotoluene in Soil Amended with Activated Carbon," In: A. Violante, P. M. Huang, J. M. Bollag and L. Gianfreda, Eds., Soil Mineral-Organic Matter-Microorganism Interactions and Ecosysstems Health, Development in Soil Science 28 B, Elsevier, Amsterdam, 2002, pp. 157 168. doi:10.1016/S0166-2481(02)80014-9

[51] G. K. Vasilyeva, L. P. Bakhaeva, E. R. Strijakova and P. J. Shea, "Biodegradation of 3,4-Dichloroaniline and 2,4,6Trinitrotoluene in Soil in the Presence of Natural Adsorbents," Environmental Chemistry Letters, Vol. 1, No. 3, 2003, pp. 176-183. doi:10.1007/s10311-003-0033-8

[52] G. K. Vasilyeva, E. R. Strijakova and P. J. Shea, "Use of Activated Carbon for Soil Bioremediation In: T. Wardowska, et al., Eds., Soil and Water Pollution Monitoring, Protection and Remediation, Springer Publishers, New York, 2006, pp. 3-23. doi:10.1007/978-1-4020-4728-2_20

[53] T. Xu, L. Lou, L. Luo, R. Cao, D. Duan and Y. Chen, "Effect of Bamboo Biochar on Pentachlorophenol Leachability and Bioavailability in Agricultural Soil," Science Total Environment, Vol. 414, 2012, pp. 727-731. doi:10.1016/j.scitotenv.2011.11.005

[54] L. Pizzul, Å. Sjögren, Md. P. Castillo and M. J. Stenstro, "Degradation of Polycyclic Aromatic Hydrocarbons in Soil by a Two-Step Sequential Treatment," Biodegradation, Vol. 18, No. 5, 2007, pp. 607-616. 
Biodegradation of 2,6-Dichlorophenol Wastewater in Soil Column Reactor in the Presence of Pineapple Peels-Derived Activated Carbon, Palm Kernel Oil and Inorganic Fertilizer

doi:10.1007/s10532-006-9093-3

[55] J. Pannu, A. Singh and O. Ward, "Influence of Peanut Oil on Microbial Degradation of Polycyclic Aromatic Hy- drocarbons," Canadian Journal of Microbiology, Vol. 49, No. 8, 2003, pp. 508-513. doi:10.1139/w03-068 